\title{
EXPLORING ACADEMIC DEVELOPMENT PROGRAMME EVALUATION AT A UNIVERSITY: A SYSTEMATIC SCHOLARLY APPROACH
}

\author{
H. Johannes* \\ e-mail: hermien.johannes@mandela.ac.za \\ T. T. Batyi* \\ e-mail: thoko.batyi@mandela.ac.za \\ S. P. Goldstone* \\ e-mail: simong@embury.ac.za
}

\author{
A-M. Olsen* \\ e-mail: anne-mart.olsen@mandela.ac.za \\ E. Champion* \\ e-mail: eunice.champion@mandela.ac.za \\ *Centre for Teaching, Learning and Media \\ Nelson Mandela University \\ Port Elizabeth, South Africa
}

\section{ABSTRACT}

The systematic review, critique and evaluation of Academic Development programmes are increasingly becoming important for informing ongoing and future programme design. Programme evaluation requires an in-depth comprehension of the programme to be evaluated (Chalmers and Gardiner 2015, 55). This article reports on the evaluation results of Academic Development programmes at the University, with the aim of constructing a conceptual and design framework for thinking about Academic Development programmes. The study applied generic impression, systems theory, reflective and evaluation lenses to determine and evaluate the characteristics of nine Academic Development programmes. The aim was to determine whether these include the promotion of conceptual change, to think differently about teaching and learning in Higher Education. Questions about why do we have Academic Development programmes and, are these needed at all, were explored. This process of moving from a "common-sense approach" (CHE $2016,168)$ to a more scholarly approach, includes evaluative-research methodologies, as well as critical reflection within a system theory paradigm. The research outcomes include a conceptual framework, data-driven programme design specifications and a blueprint for a generic Academic Development programme design.

Keywords: higher education, academic development, programme evaluation, programme design enhancing teaching and learning, data-driven programme design specifications

\section{BACKGROUND AND INTRODUCTION}

Academic Development (AD) in Higher Education (HE) includes various aspects of teaching and learning development support for staff and students alike. According to Bamber (2008) AD programmes can be evaluated effectively by applying theory-informed evaluation research approaches in the natural settings of the programmes (Bamber 2008, 108). Over time, assorted $\mathrm{AD}$ offerings by a Centre for Teaching and Learning (henceforth Centre) of a South African Comprehensive University (henceforth University) have expanded organically into nine AD 
programmes, which comprise the subject of this investigation. The Council on Higher Education (CHE) (2004) describes a programme as "a purposeful and structured set of learning experiences that leads to a qualification" (CHE 2004, 36). However, as only a few of the nine offered programmes lead to a qualification, a broader description for AD programmes was adopted and it states: Academic Development programmes can be described as "purposeful and structured sets of learning, teaching and assessment experiences, together with a scholarly approach that leads to the changing of teaching practices". The SA Education White Paper 3 (CHE 1997 Chapter 2.5, 12) states: "A programme-based approach recognises that higher education takes place in a multiplicity of institutions and in various sites of learning, utilising a variety of methods, and attracting an increasingly diverse body of learners". Therefore, although AD programmes are complex, and not easy to describe, several key attributes capture the essence of these as "system interconnectedness; multiple stakeholders; multi-levelled and multiple formats; and emerging outcomes" (CGIAR 2013, 3). Academic Development programmes include a variety of programme modes, namely short-learning programmes, in situ training, academic working groups, consulting, peer assessment and mentoring, one-on-one support, student assessment of teaching, as well as intensive staff-development programmes (Prebble et al. 2004, 25). The AD programmes reported on in this article include all the programme modes mentioned above to a greater or lesser extent.

Within a context of a third generation of AD (Boughey 2007), the AD Centre's Indaba provided opportunities for reflection on, and informal analysis of its $\mathrm{AD}$ offerings. This led to a conceptualisation of a programme-based approach to $\mathrm{AD}$, which contributed to the structure of the AD focus, by providing general, as well as, specific structural elements. These included format, purpose, approach, alignment with other programmes, role-players and roles, processes and procedures, and programme outcomes. (Table 5). The diverse complexity of the emerging AD programmes both enriched and fragmented the programme-based approach adopted by the Centre. For example, horizontal and vertical non-alignment required not only evaluation and redesign of the individual programmes, but it also highlighted the need for a new generic programme design contextualised within the HE system. The CHE $(2017,16)$ states that the "role of academics as teachers encompass teaching as delivery, programme design, evaluation, and the scholarship of teaching and learning". Building capacity through systemic and collaborative research between academic developers, and academics allows for professional learning on both sides (CHE 2017, 17).

The rationale for the study was to move "from a common-sense approach to a more systematic, scholarly approach" to AD (CHE 2016, 168) via an evaluation research process to analyse and evaluate nine AD programmes offered by the Centre at the University. Prominent 
themes highlighted in the CHE review of HE (CHE 2016) are represented, either as a main theme or embedded in all our programmes namely, teaching and learning with technology, academic literacies, multilingualism, SoTLC and AD research (Figure 1).

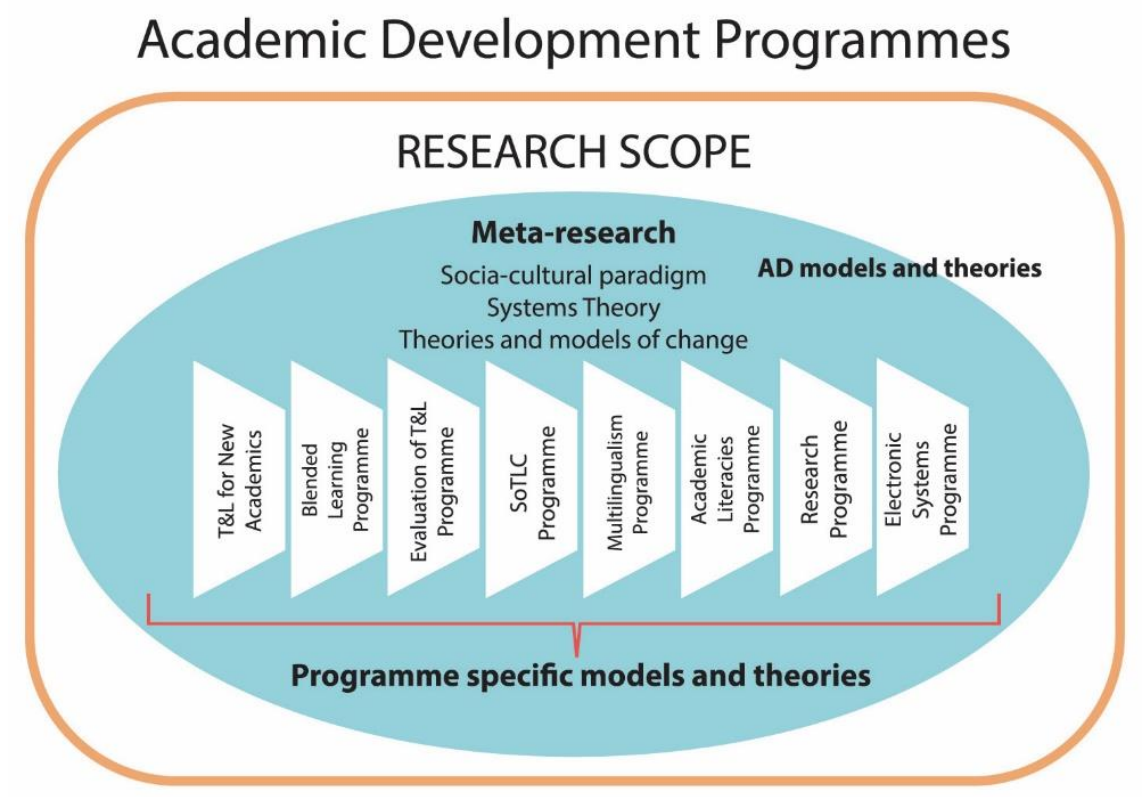

Figure 1: Nine AD Programmes at the University

The departure point was not the under-preparedness of the academic staff, but rather, participatory communities of practice within AD and faculties, the institutional Vision 2020 and supportive development plans. These have implications for the ways of doing, and how the programme modes and models are applied to effect a range of outcomes. The aim of the study was to align and integrate programmes that have become disconnected, to avoid the so-called AD rag-bag approach, carrying on from year-to-year with the status quo (McAlpine et al. 2009). In so doing, the $\mathrm{AD}$ team realised that academic developers need to develop their own practices, and to reflect critically on AD programmes at the University. The authors concur with the views expressed by CALPRO (1997), which emphasise the importance of ongoing and systematic evaluation procedures for professional [academic] development activities. The reasons for this include the increasing demands on resources, as well as, the demands for accountability. As CALPRO clearly states, "Professional [Academic] development is about CHANGE with the purpose to improve learner outcomes by changing instructional behaviour to achieve a predetermined goal" (CALPRO 1997, 4-2). The change process affects not only a number of roleplayers, e.g. the academic developers, academic staff ("students"), and the relevant programmes, but also subsequent student learning (Ho 1998; Ho 2000; Ho, Watkins and Kelly 2001). 
Numerous studies suggest frameworks for indicators of effectiveness and the evaluation of AD (Chalmers and Gardiner 2015, 63). One example is Guskey's (2002) five-level model which provides a useful matrix for decision-making. This model includes participants' reactions to the programme, conceptual change in participants' thinking, identifying changes in institutional culture, behavioural changes, and identifying changes in student learning. Some examples of focus areas are participant reactions, organisational support, participants' use of new knowledge, conceptual and behavioural change, and the impact on student learning (CALPRO 1997; Kutner et al. 1997; Chalmers and Gardiner 2015; Gibbs and Coffey 2004; Guskey 2002; Gilbert and Gibbs 1998; Weis and Klein 2005/2006). The research group was encouraged by the work of the aforementioned authors, particularly Chalmers and Gardiner $(2015,53)$ who state that, "there is a need for research on systematic measurement on the effectiveness of these programmes". Research conducted by Chalmers and Gardiner (2015) only became available to the research group at the University after the research, on which this article is based, was conducted. Informal comparison between the research group's work and Chalmers and Gardiner's (2015) research approach and findings were highly motivating, and supportive of our conceptual and theoretical frameworks (Figures 2, 4 and 5). Chalmers and Gardiner (2015) identify four types of quality indicators of the impact and effectiveness of AD programmes, commonly used as input; output; process and outcome indicators. They further describe their effectiveness framework as a "matrix of indicators related to the intended outcomes" within an institutional context (Chalmers and Gardiner 2015, 64, 66). The institutional context for this study contributes an enabling environment for authentic programme offerings, customised for relevance, underpinned by theory, practice, research and real world features to accommodate a variety of needs. These are illustrated by the variety of offerings (different modes) available at the university. However, before "impact" could be evaluated, the basic input into the equation should be examined. Therefore, the first step in the process of a systematic scholarly approach to AD programme evaluation should be to explore, analyse and describe the input into the system. The input would include inter alia the nature/characteristics, structure and components of the programme to be evaluated. Joyce and Showers (1995) are of the opinion that "To link professional development activities and student learning, there must be potent content and a good design, not only of professional development, but of the organization in which that content is to be implemented" (Joyce and Showers 1995, in Kutner et al. 1997, 2). Kutner et al. (1997) continue by highlighting ongoing programme enhancement and accountability as two important roles that evaluation plays in the AD process (Kutner et al. 1997, 2). Various evaluation frameworks indicate the importance of the evaluation design and ongoing monitoring (CGIAR 2013), whilst others focus on the evaluation process 
(Kurtner et al. 1997, 4) or sequence and stages (reaction, learning, behaviour, and results) of evaluation actions (Killion 2006, 5). Kutner et al. (1997) describe three targets, namely, the instructor, the adult student and the program, as the legs of an "essential triangle for change" (Kurtner et al. 1997, 4). The AD research team at the University identified a fundamental gap in some of these evaluation frameworks. Many of these frameworks include participants' evaluation feedback and self-reporting evaluations, as well as subjective observation methods, without questioning or analysing the starting point (input into the system), which is the programme attributes. Programme attributes are essential inputs in the triangle of change. Identifying programme attributes, such as the structure, components, features, and characteristics to describe the nature of the programme and to map these to the required programme outcomes, are frequently overlooked. Another core feature not always recognised as such, is the importance of programme theory, also called a logical model or impact pathways (MMWR 1999, 3) and the theories of change (CGIAR 2013, 3; MMWR 1999, 3). Hence, this research study aims to map the linkages and pathways between the legs of the triangle, although the programme leg of the triangle is the focus of this article. The structure of the article includes an explanation of the evaluation research design, with theoretical underpinnings, research lenses, methodology, data collection, analysis, findings and a conclusion. The second cycle described elsewhere, focuses on to what extent redesigned AD programmes include the key elements of effecting conceptual change. The third cycle focuses on data-driven impact design for $\mathrm{AD}$ programmes in $\mathrm{HE}$.

\section{EVALUATION RESEARCH DESIGN}

The selected evaluation research design includes interpretive meta-theories, as well as qualitative, quantitative and participatory methods. Mouton (2001) describes qualitative or naturalistic evaluation research approaches, as programme evaluation in natural settings. Mouton $(2001,158)$. The study population included all existing, as well as emerging, AD programmes at the Centre and, due to the small number involved, no sample selection was included. Relevant literature, programme-evaluation practices and research studies guided the research design and the methodologies utilised. The participants are seen as being integral to the study design and the research activities. Research participants act in a number of roles, namely programme evaluators of the programmes, which they co-ordinate, reflective practitioners and participatory researchers. The "evaluation approach is best suited to actionoriented evaluation questions" (Rogers and Williams 2006, 83-84), and as such, these were applied to determine each programme's attributes. We concur with Chalmers and Gardiner (2015) who argue that "systematic measurement of impact and effectiveness of AD 
programmes needs to move from the research paradigm to the evaluation paradigm to inform ongoing and future teacher development programs and enhancement" (Chalmers and Gardiner $2015,53)$. For each programme, design components, conceptual and theoretical frameworks, plus epistemologies were analysed, reviewed, evaluated on various levels, interpreted, and given critical reflection.

\section{PARADIGM, THEORETICAL AND CONCEPTUAL FRAMEWORKS}

Inductive abductive reasoning guided the research design to choose the best explanation for a phenomenon by using flexible approaches to contribute to useful evaluations. (Wikipedia n.d.; Shadish, Cook and Leviton 1991, 404; Patton 1997, 17, cited in Patton 2002). Within the research team, $\mathrm{AD}$ and the research context, the possibilities for constructing theoretical and conceptual frameworks for thinking about AD programmes at the University, were explored. An important aim of $\mathrm{AD}$ programmes is to effect conceptual change, thinking differently about teaching, learning and assessment, which could result to change in the teaching practice that can impact positively on student learning. Therefore, this purpose should be reflected by the input elements of the programmes, with ongoing change as an operating principle. Here, we drew on systems theory, models of change and models of action. Capra (1997) and Senge (2006) identified a number of system theory principles which guided our thinking. These are:

- Every system is defined by specific characteristics (input) organised in patterns of relationships. The processes in the system are the interactional activities, in which the system engages. Structure is the way in which the patterns in the system are expressed; and they reflect the system output.

- The "whole system is greater than the sum of the parts" (Capra 1997, 3).

- These parts can be described as input; process; output; outcome and feedback loops, within a specific context. Each part has identifying characteristics, or attributes, and the arrangement between the attributes are defined as patterns. Systems are not concretely visible; but they are organised patterns of relationships (Berens 2013).

- These relationships are influenced by output-input feedback loops, as well as by the environment. For example, specific interventions and system drivers, which may accelerate the process.

- Nested arrangements of structures, where one is contained within the next.

- $\quad$ Systems might exist as sub-systems of larger systems.

- $\quad$ Systems theory emphasises ongoing change.

Figure 2 illustrates the application of the above principles to develop a theoretical framework 
for this study. Each AD programme (labelled as $\mathbf{A}$ ) has a structure consisting of different input elements, with distinctive characteristics arranged in different patterns of relationships. Input elements include the different role-players and their roles, the different programme characteristics, such as the alignment and format organised in unique patterns of relationships for each programme. The holistic theme of the pattern can be described as purpose (labelled as B) (Berens 2013). Interventions (labelled as C) applied to the interactional activities, in which the system engages may change the output (labelled as $\mathbf{D}$ ) and the outcome (labelled as $\mathbf{E}$ ). The initial analysis of the system parts, as well as the relationships between them within a specific environment, need to be unpacked, and described, in order to be able to determine the nature of each programme (system/sub-system), and to differentiate between them.

Logic models are graphical ways to organise information and to display thinking, which provided the team with a snapshot of their current thinking on AD programmes, programme activities, planned actions and outcomes (Millar, Simeone and Carnevale 2001; Knowlton and Phillips 2013, 3; Weis and Klein 2005/2006, 3). For this study, logic models were applied to programme evaluation and programme design (Knowlton and Phillips 2013, 4).

We also drew on Knowlton and Phillips $(2013,3)$ to identify two types of models described as "A theory of change (conceptual), which is a portrayal of how change would occur, and programme logic models" (operational). The latter include more detail about resources, planned activities, and the outputs and outcomes. These visual representations of the team's ideas helped to firstly, share understanding of relationships among the programme elements necessary to operate the programme and change efforts and secondly, to see the linkages and pathways between one's programmes, and how to map these and turn actions into results (Killion 2006, 5). This process includes interactive evaluation and review, reflection, and identifying trends and patterns. The outcome of the process fed back into the system, as the design specifications for revised programmes. Furthermore, the change implementation resulted in three elements namely creating awareness; promoting engagement; and fostering commitment.

The model of change we adopted comprised of a sequence of actions that could create awareness, engagement and commitment, to effect conceptual change to think differently about teaching practice. Weisburd and Snaid (2005/2006) state that a theory of action "maps out a specific pathway in that theory of change with respect to achieving that change" (Weisburd and Snaid 2005/2006, 20). Both the theories (of change and of action) informed our programme design, development and implementation. For example, the model of change illustrated in Figure 3. 


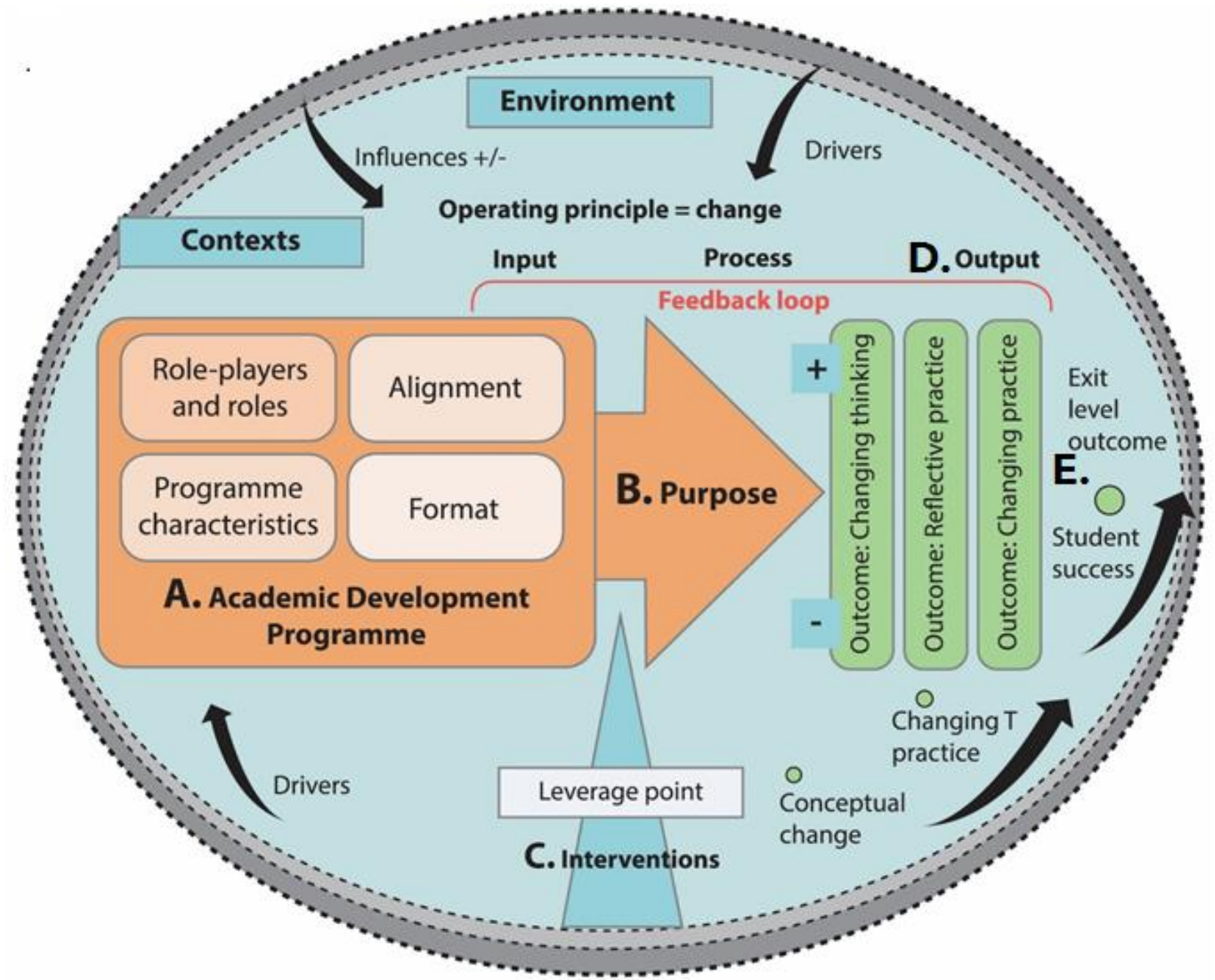

Figure 2: AD System Theoretical Framework

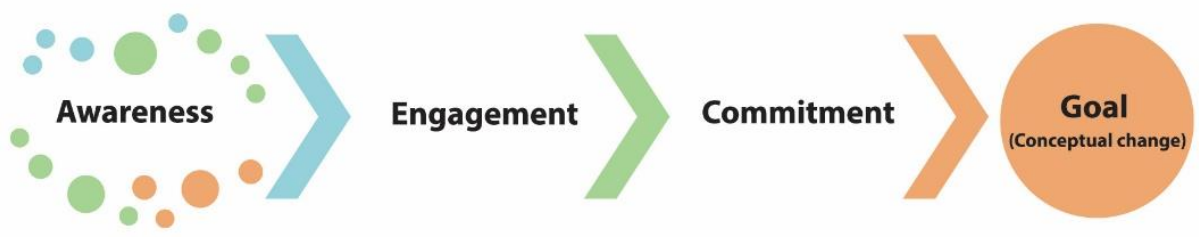

Figure 3: Model of Change

Our programme blueprint included design specifications, aimed at outcomes to effect conceptual change, and the programme logic model for the living AD programme system illustrated in Table 1.

As illustrated in Table 1, the knowledge domains include academic literacies, subject specific knowledge, teaching and learning related to student success, teaching and learning related to academic staff attributes, HE studies related to academic developers' attributes and $\mathrm{AD}$ administration related to data reports and feedback back into the system as input. 
Table 1: Programme Logic model to illustrate the Living AD programme system components

\begin{tabular}{|c|c|c|c|c|c|c|c|}
\hline Programme & $\begin{array}{l}\text { Knowledge } \\
\text { Domain }\end{array}$ & $\begin{array}{l}\text { Main role } \\
\text { players }\end{array}$ & Input & Processes & Intervention & Output & Outcomes \\
\hline $\begin{array}{l}\text { Academic literacies } \\
\text { Multilingualism }\end{array}$ & $\begin{array}{l}\text { Academic } \\
\text { literacies; } \\
\text { Teaching } \\
\text { writing in } \\
\text { disciplinary } \\
\text { spaces }\end{array}$ & $\begin{array}{l}\text { Students } \\
\text { Academics } \\
\text { Supervisors }\end{array}$ & $\begin{array}{l}\text { Student and } \\
\text { academic } \\
\text { learning } \\
\text { opportunities }\end{array}$ & $\begin{array}{l}\text { Student and } \\
\text { academic } \\
\text { development }\end{array}$ & $\begin{array}{l}\text { Student and } \\
\text { academicl } \\
\text { Supervisor } \\
\text { teaching and } \\
\text { learning }\end{array}$ & $\begin{array}{l}\text { Exit level } \\
\text { outcomes } \\
\text { Subject } \\
\text { learning }\end{array}$ & $\begin{array}{l}\text { Graduate } \\
\text { attributes } \\
\text { Academic } \\
\text { staff teaching } \\
\text { attributes }\end{array}$ \\
\hline $\begin{array}{l}\text { Multilingualism } \\
\text { Academic literacies } \\
\text { Blended Learning } \\
\text { Assessment }\end{array}$ & Subject & $\begin{array}{l}\text { Students } \\
\text { Academics }\end{array}$ & $\begin{array}{l}\text { Teaching and } \\
\text { learning } \\
\text { practices }\end{array}$ & $\begin{array}{l}\text { Learning } \\
\text { opportunities } \\
\text { Assessment } \\
\text { opportunities }\end{array}$ & $\begin{array}{l}\text { Teaching } \\
\text { and learning } \\
\text { activities }\end{array}$ & $\begin{array}{l}\text { Subject } \\
\text { learning }\end{array}$ & $\begin{array}{l}\text { Student } \\
\text { success }\end{array}$ \\
\hline $\begin{array}{l}\text { Multilingualism } \\
\text { Academic literacies } \\
\text { Blended Learning } \\
\text { Assessment } \\
\text { SoTLC* } \\
\text { Teaching evaluation }\end{array}$ & $\begin{array}{l}\text { Teaching and } \\
\text { learning }\end{array}$ & Academics & $\begin{array}{l}\text { Discipline/ } \\
\text { subject } \\
\text { teaching } \\
\text { practices }\end{array}$ & $\begin{array}{l}\text { Teaching } \\
\text { opportunities }\end{array}$ & $\begin{array}{l}\text { Teaching } \\
\text { activities }\end{array}$ & $\begin{array}{l}\text { Discipline / } \\
\text { subject } \\
\text { learning }\end{array}$ & $\begin{array}{l}\text { Student } \\
\text { success }\end{array}$ \\
\hline $\begin{array}{l}\text { Blended Learning } \\
\text { Assessment SLP } \\
\text { SoTLC } \\
\text { Teaching and } \\
\text { learning } \\
\text { Introduction } \\
\text { Teaching evaluation }\end{array}$ & $\begin{array}{l}\text { Teaching and } \\
\text { learning in } \\
\text { higher } \\
\text { education } \\
\text { (HE) }\end{array}$ & $\begin{array}{l}\text { Academics } \\
\text { Academic } \\
\text { Developers } \\
\text { (ADr) }\end{array}$ & $\begin{array}{l}\text { Teaching } \\
\text { practices in } \\
\text { HE } \\
\text { AD practices }\end{array}$ & $\begin{array}{l}\text { Learning } \\
\text { opportunities } \\
\text { Teaching } \\
\text { opportunities } \\
\text { Assessment } \\
\text { opportunities }\end{array}$ & $\begin{array}{l}\text { Teaching } \\
\text { and learning } \\
\text { activities }\end{array}$ & $\begin{array}{l}\text { Teaching, } \\
\text { learning and } \\
\text { assessment } \\
\text { in subject } \\
\text { domain }\end{array}$ & $\begin{array}{l}\text { Academic } \\
\text { staff } \\
\text { attributes } \\
\text { (subject } \\
\text { expert) }\end{array}$ \\
\hline $\begin{array}{l}\text { Research } \\
\text { programme } \\
\text { All programmes }\end{array}$ & $\begin{array}{l}\text { Higher } \\
\text { Education } \\
\text { Studies } \\
\text { (HES) }\end{array}$ & $\begin{array}{l}\text { Academic } \\
\text { Developer } \\
(A D r)\end{array}$ & $\begin{array}{l}\text { AD research } \\
\text { practices }\end{array}$ & $\begin{array}{l}\text { Research } \\
\text { opportunities }\end{array}$ & $\begin{array}{l}\text { Research } \\
\text { activities }\end{array}$ & $\begin{array}{l}\text { Teaching, } \\
\text { learning and } \\
\text { assessment } \\
\text { in HES }\end{array}$ & $\begin{array}{l}\text { ADr } \\
\text { attributes ( } T \text {, } \\
L \text { and } A \text { in } \\
\text { HE expert) }\end{array}$ \\
\hline $\begin{array}{l}\text { AD programmes } \\
\text { TDODS** }\end{array}$ & $\begin{array}{l}\mathrm{AD} \\
\text { administration }\end{array}$ & $\begin{array}{l}\text { ADr } \\
\text { Electronic } \\
\text { systems }\end{array}$ & $\begin{array}{l}\text { Administration } \\
\text { data }\end{array}$ & $\begin{array}{l}\text { Database } \\
\text { population }\end{array}$ & Data queries & Reports & $\begin{array}{l}\text { Data to } \\
\text { inform } A D\end{array}$ \\
\hline
\end{tabular}

${ }^{*}$ SoTLC - Scholarship of Teaching and Learning Certificate

${ }^{* *}$ TDODS - Teaching Development Online Database System

Contextualising the nine AD programmes within the Living AD Programme System shows the system levels nested into each other, as sub-systems of the levels above, and also as the parts of the whole, namely, the living AD Programme system (Figure 4).

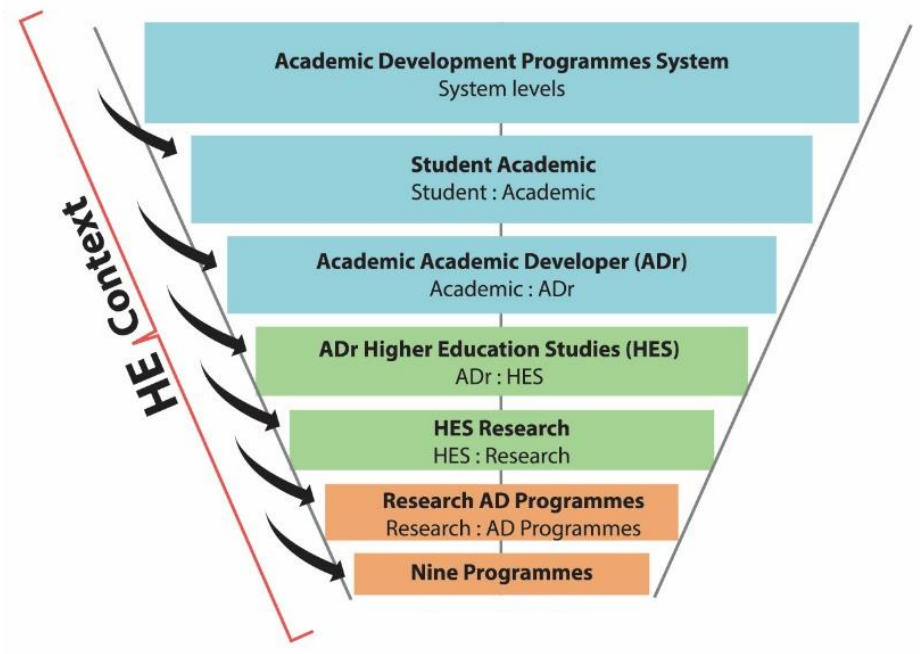

Figure 4: Academic Development Programme System Levels Nested as Sub-systems 
Each part of the system is linked to a specific programme logic model, as well as the characteristics, purpose, content and context of each programme. Conceptualising and visualising linkages and pathways among the different parts of the whole, resulted in a coherent whole, represented as a conceptual framework (Figure 5).
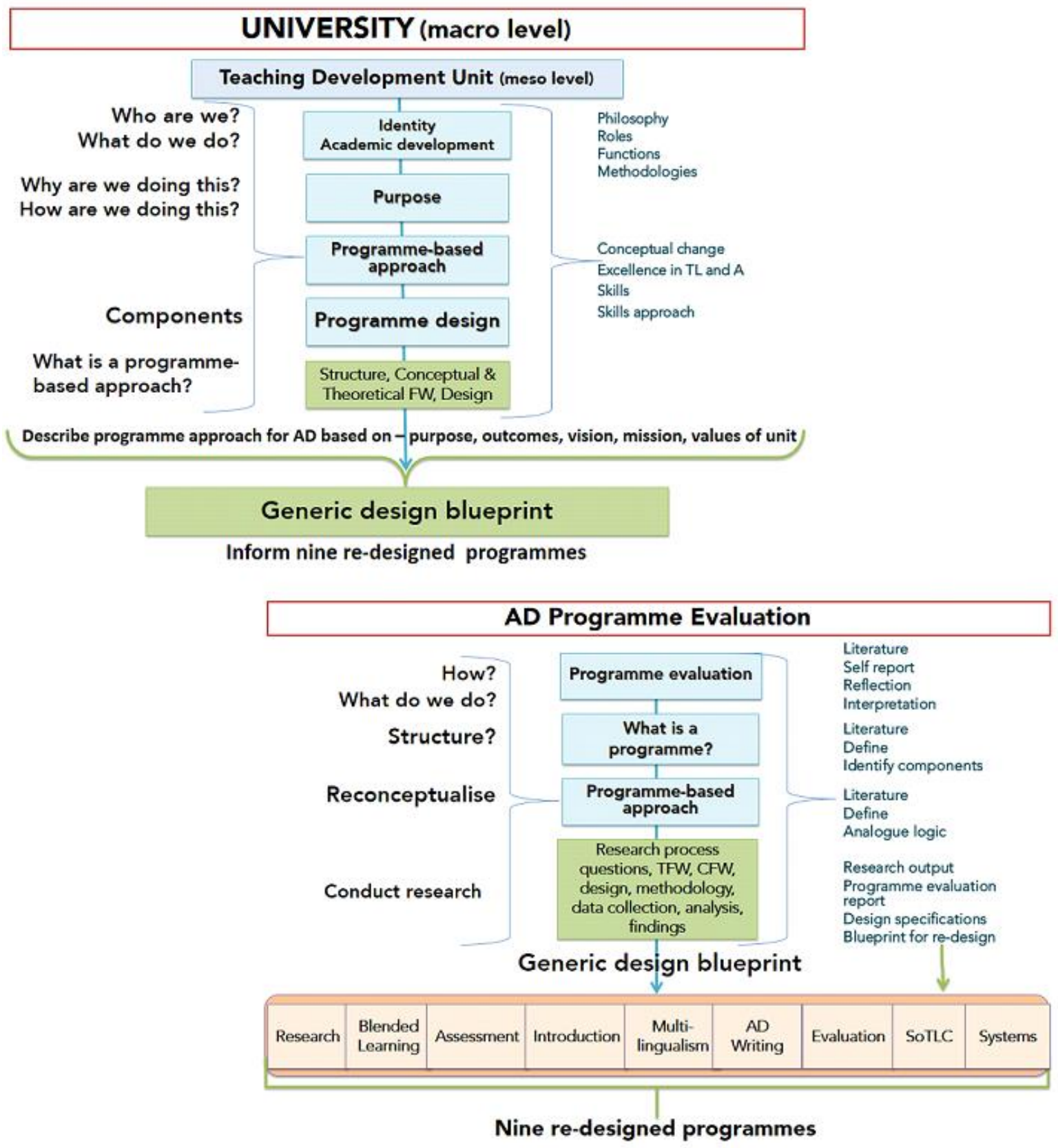

Figure 5: Conceptual Framework

Visible in this conceptual framework are the linkages and pathways to the research questions. Thus, the conceptual framework provided a point of departure for the research design, and it made the underlying structure, characteristics and elements of $\mathrm{AD}$ programmes for future programme designs explicit. 
Programme characteristics, purpose, content and context, linked to the models of change and of action, relevant for this study.

\section{RESEARCH METHODOLOGIES}

Following are the research questions that informed the project:

1. What is a programme-based approach for AD programmes at the University?

Q1.1 What is a programme-based approach?

Q1.2 What is the composition of AD programmes at the University (Tabled programme components)?

2. What is the nature of the AD programmes at the University?

Q2.1 What is the nature of the nine programmes offered by the Centre (Official programme review document)?

Q2.2 How to apply interactive evaluation to customise the review document (Analogue thinking)

Q3 What are the design specifications for programmes, in order to reflect the purpose of conceptual change? (Second review process)

The mapping of the data-collection-research techniques to the research questions is tabled in Table 2.

Table 2: Mapping data collection research techniques to the research questions

\begin{tabular}{|c|c|c|c|c|c|c|c|c|c|}
\hline Research questions & 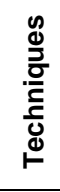 & 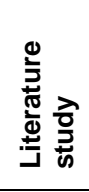 & 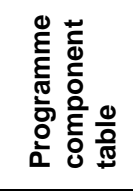 & 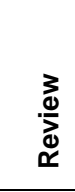 & 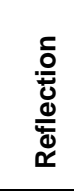 & 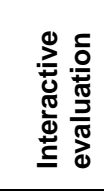 & $\begin{array}{l}z \\
\sum_{0}^{0} \\
\widetilde{x}\end{array}$ & 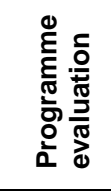 & 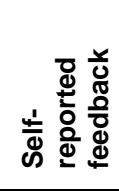 \\
\hline \multicolumn{2}{|l|}{ Q1.1 What is? } & $\checkmark$ & $\checkmark$ & $\checkmark$ & $\checkmark$ & & & & $\checkmark$ \\
\hline \multicolumn{2}{|l|}{ Q1.2 Components } & $\checkmark$ & $\checkmark$ & $\checkmark$ & $\checkmark$ & & & & $\checkmark$ \\
\hline \multicolumn{2}{|l|}{ Q2.1 Nature } & $\checkmark$ & $\checkmark$ & $\checkmark$ & $\checkmark$ & $\checkmark$ & $\checkmark$ & $\checkmark$ & $\checkmark$ \\
\hline \multicolumn{2}{|l|}{ Q2.2 Instrument } & & & & $\checkmark$ & $\checkmark$ & & $\checkmark$ & $\checkmark$ \\
\hline \multicolumn{2}{|c|}{ Q2.3 Design specifications } & $\checkmark$ & $\checkmark$ & & & $\checkmark$ & $\checkmark$ & $\checkmark$ & $\checkmark$ \\
\hline
\end{tabular}

To answer the research questions, the data-collection techniques were chosen to firstly, provide insight into answering the "what" questions about AD programmes, such as, "What is a programme-based approach?" "What is a programme?" "What are the components, characteristics, structure and nature of an AD programme?" Here, we drew on the literature, as well as the programme conceptualisations and descriptions based on the AD Centre's Indaba, where the programme co-ordinators of each programme proceeded to document their 
programmes, based on their experience and the implementation of their programmes. Using the programme component framework to unpack the current practice, each programme coordinator analysed the "what", and "why" part of their AD practices and the outcomes of this included:

- A populated table and programme description for each programme, and

- Evaluation reports to indicate mapping between the programme components and the programme requirements.

- Reflections on each programme.

- Suggestions for interventions and design modifications for programme redesign, in order to satisfy the programme requirements.

This led to the next question, "What is the purpose of each programme?" Collective reasoning indicates that the purpose for each programme is to effect conceptual change, to think differently about practices, to do differently, aiming at students' success. Secondly, a review process using the official template for programme review was applied to each programme, to evaluate the programme characteristics. The outcome of this process consisted of selfevaluation reports for each programme. Interactive evaluation-interventions resulted in a refined evaluation instrument, which was applied to a second round of programme reviews. The outcomes of this process were updated self-evaluation reports, together with the interpretation thereof, graphical-data representations, reflections and conclusions to answer the question: "Does the programme meet the set requirements, in order to effect conceptual change?" Finally, a synthesis process to consolidate the findings not only on the programme level, but also on the meso level, to provide input into a data-driven generic AD programme design.

Although the research methodology and the programme evaluation steps are arranged in an ordered list for clarification, the participatory evaluation research paradigm and the nature of the study allowed for recurring action cycles. As the team evaluated their AD programmes, thought about and explored their own practices, new insights and conceptions came forth. These acted as powerful and energising drivers for the research process. The methodology and programme-evaluation steps to guide the thinking and the action plans are listed in Table 3.

Table 3: A stepped approach to guided thinking and plan actions

1. Schedule regular team meetings for action planning activities, feedback reports on study progress, collaborative work.

2. Develop action plan: The action plan acted not only as a directive for research actions, but also gave structure to contextualise the study cycles and activities. For example, making choices about the starting point, scope, theories of change, and theoretical frameworks for the study. 


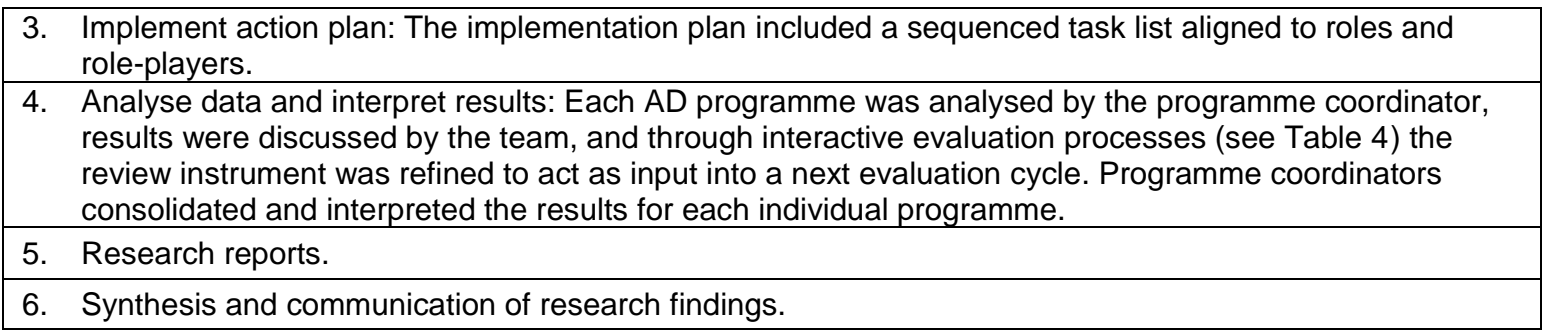

\section{PROGRAMME EVALUATION AND DATA COLLECTION}

We developed a 15-step process (Table 4) using, what Killion (2006) refers to as, "a theory of change-evaluation modelling and building on the logic models that define the conceptual change process". This encouraged evaluators to build pathways with evidence to improve the AD programme design (Killion 2006, 5). The evaluation process started with a literature review; and it concluded with a final report (Table 4). Programme evaluation steps, evaluation actions and outcomes are listed in Table 4.

Table 4: Programme Evaluation Outcome

\begin{tabular}{|c|c|c|c|}
\hline & Evaluation steps & Actions & Output \\
\hline 1 & $\begin{array}{l}\text { Literature review to define } \\
\text { concepts, determine scope, } \\
\text { improve knowledge on } \\
\text { programme evaluation }\end{array}$ & $\begin{array}{l}\text { Summaries to team during meetings } \\
\text { Team discussions } \\
\text { Posted in online collaboration space } \\
\text { Online discussions }\end{array}$ & $\begin{array}{l}\text { Literature study document } \\
\text { Online research collaborative space }\end{array}$ \\
\hline 2 & $\begin{array}{l}\text { Select evaluation } \\
\text { frameworks }\end{array}$ & $\begin{array}{l}\text { Online searches } \\
\text { Apply programme component } \\
\text { framework and } \\
\text { Official review documents }\end{array}$ & $\begin{array}{l}\text { Selected evaluation frameworks } \\
\text { namely the Programme component } \\
\text { framework and the University } \\
\text { programme review template }\end{array}$ \\
\hline 3 & Logic models & Select appropriate model & Logic model for programme \\
\hline 4 & Theoretical underpinnings & $\begin{array}{l}\text { Select appropriate theories: } \\
\text { Social cultural theoretical } \\
\text { underpinnings } \\
\text { System theory and system thinking } \\
\text { Theories of change }\end{array}$ & $\begin{array}{l}\text { Theoretical framework and } \\
\text { conceptual framework }\end{array}$ \\
\hline 5 & $\begin{array}{l}\text { Select evaluation } \\
\text { instruments and questions }\end{array}$ & $\begin{array}{l}\text { Use institutional evaluation / review } \\
\text { instruments with pre-set questions }\end{array}$ & Review template \\
\hline 6 & $\begin{array}{l}\text { Conduct and complete } \\
\text { programme reviews }\end{array}$ & $\begin{array}{l}\text { Evaluate and review each } \mathrm{AD} \\
\text { programme. Complete the review } \\
\text { template }\end{array}$ & $\begin{array}{l}\text { Completed self-evaluation } \\
\text { programme review reports }\end{array}$ \\
\hline 7 & $\begin{array}{l}\text { Reflect on self-evaluation } \\
\text { report }\end{array}$ & $\begin{array}{l}\text { Each programme coordinator } \\
\text { critically reflects on the completed } \\
\text { self-evaluation report }\end{array}$ & Reflective reports \\
\hline 8 & Refine evaluation instrument & $\begin{array}{l}\text { Identify gaps in the evaluation } \\
\text { instrument } \\
\text { Reflective team discussion } \\
\text { Interactive evaluation and } \\
\text { refinement of the instrument }\end{array}$ & Refined instrument \\
\hline 9 & $\begin{array}{l}\text { Re-evaluate programmes } \\
\text { and complete self-evaluation } \\
\text { reports }\end{array}$ & $\begin{array}{l}\text { Each programme coordinator } \\
\text { re-evaluate their programmes }\end{array}$ & $\begin{array}{l}\text { Refined self-evaluation programme } \\
\text { review reports }\end{array}$ \\
\hline 10 & Group discussions on results & $\begin{array}{l}\text { Team meeting to discuss the } \\
\text { reports and graphs }\end{array}$ & $\begin{array}{l}\text { Graphical presentation of results for } \\
\text { each programme } \\
\text { Consolidated summary in graphical } \\
\text { format }\end{array}$ \\
\hline 11 & Interpret results & $\begin{array}{l}\text { Each programme coordinator } \\
\text { interpreted their programme results. } \\
\text { The study leader consolidated } \\
\text { findings }\end{array}$ & Consolidated report \\
\hline 12 & Recommend programme & Each programme leader listed & Programme specification lists \\
\hline
\end{tabular}




\begin{tabular}{|l|l|l|l|}
\hline & Evaluation steps & Actions & Output \\
\hline & changes & proposed programme changes & Blueprint document for programme \\
new design & $\begin{array}{l}\text { Set educational outcomes } \\
\text { Use the programme specification } \\
\text { lists and blueprint document for new } \\
\text { generic programme design }\end{array}$ & design \\
\hline 14 & Consolidate results & $\begin{array}{l}\text { Use the programme specifications } \\
\text { and blueprint documents as input } \\
\text { for a generic programme design } \\
\text { Design generic programme for AD }\end{array}$ & Generic programme design \\
\hline 15 & Report on findings & Write final report and paper & Final report and paper \\
\hline
\end{tabular}

From Table 4 it is evident that multiple methods of data collection were applied. These included the application of selected evaluation frameworks, evaluation and review templates, interactiveevaluation techniques, analysing existing and newly created document sources, team-meeting discussions and minutes, reflective notes, and reports. The data sources included the evaluation data and the participant feedback on eight of the nine existing AD programmes. The research programme is new, and the current programme data are insufficient for analysis.

\section{DATA ANALYSIS AND FINDINGS FOR THE PROGRAMME EVALUATION}

Analysis of the data captured by applying the evaluation frameworks (programme component framework and review template, steps 6 and 7) to AD programmes revealed the following programme characteristics:

1. Programme descriptions of the programmes are based on the Centre's Indaba, where the programme co-ordinators of each programme proceeded to document their programmes, based on their experience and the implementation of their programmes.

2. The programme component framework was an acceptable and useful framework to capture the characteristics of AD programmes.

\section{The framework consists of the following components:}

Format, purpose, approach, alignment with other programmes, role-players and roles, processes and procedures, programme outcomes.

The analysis of each $\mathrm{AD}$ programme component summarises $\mathrm{AD}$ programmes at the University as various combinations of programme specific characteristics in Table 5.

Table 5: Programme Component Framework

\begin{tabular}{|l|l|l|}
\hline & Component & AD programme characteristics \\
\hline 1 & Format & $\begin{array}{l}\text { Electronic, online database platform, blended learning, interactive, formal credit } \\
\text { bearing, informal, voluntary, developmental, individual, department and faculty } \\
\text { levels, Short Learning Program, workshops, consultations, monitoring, mentoring, } \\
\text { dialogue. }\end{array}$ \\
\hline 2 & Purpose & $\begin{array}{l}\text { Providing collaborative spaces for programme specific development. To conduct } \\
\text { Scholarship of Teaching and Learning research. To engage in dialogue and to } \\
\text { build relationships. Building communities of practice. Optimise procedures. Data }\end{array}$ \\
\hline
\end{tabular}




\begin{tabular}{|l|l|l|}
\hline & Component & AD programme characteristics \\
\hline 3 & Approach & $\begin{array}{l}\text { capture, analysis, and reports. Introducing new academics into institutional and } \\
\text { teaching and learning culture. To enhance and facilitate teaching, learning and } \\
\text { assessment opportunities for academics and students, epistemological access. }\end{array}$ \\
\hline 4 & $\begin{array}{l}\text { Alignment with } \\
\text { approach, facilitative, humanising pedagogy, strategic, structured, systems } \\
\text { approaches, active learning, participatory dialogue, promoting SoTL, curriculum } \\
\text { design. }\end{array}$ \\
\hline 5 & $\begin{array}{l}\text { Role-players and } \\
\text { roles }\end{array}$ & $\begin{array}{l}\text { All AD programmes, selected academic programmes, administration and HR } \\
\text { programmes. }\end{array}$ \\
\hline 6 & $\begin{array}{l}\text { Processes and } \\
\text { procedures }\end{array}$ & $\begin{array}{l}\text { Programme designer, study leader, academics, academic developers and } \\
\text { academic departments, faculties, students, teaching and learning committees. }\end{array}$ \\
\hline $\begin{array}{l}\text { Regulated by teaching and learning policies; Vission2020; university strategic } \\
\text { plan; Programme specific processes and procedures inter alia reflection, analysis, } \\
\text { development, planning and implementation, evaluation, statistics and reporting, } \\
\text { training, academic development activities. }\end{array}$ \\
\hline 7 & $\begin{array}{l}\text { Programmes } \\
\text { outcomes }\end{array}$ & $\begin{array}{l}\text { Certification, policy development, adoption of new approaches and practices, } \\
\text { create awareness of programme specific goals, demonstrate knowledge gained, } \\
\text { engagement across boundaries, curriculum development, encourage reflective } \\
\text { practice; place interventions in line with institutional culture, accelerated change } \\
\text { implementation }\end{array}$ \\
\hline
\end{tabular}

4. Review results from the self-evaluation reports were analysed, and a summary of the AD programme review results is presented in Figure 6.

From the graph (Figure 6), it is clear that all the programmes are aligned with the institutional mission, its strategic priorities and academic focus areas. Furthermore, the average rating was 2.02, which indicates that all the AD programmes meet the minimum standards. Exceptions include criteria 17, 22-24 and 26-27, which were applicable to the Short Learning Programme and the two formal programmes linked to a postgraduate programme, and selectively to the others. The team discussed the results; and through a process of interactive evaluation, reached consensus on the following:

1. Add another category for judgement, namely a rating of five to indicate a choice of "not applicable".

2. Change the wording of some of the questions, for example reference to students to be read as staff (staff being the students).

3. Add descriptive titles for the criteria.

4. Apply the refined evaluation instrument to review the programmes, and compile a collaborative report. 


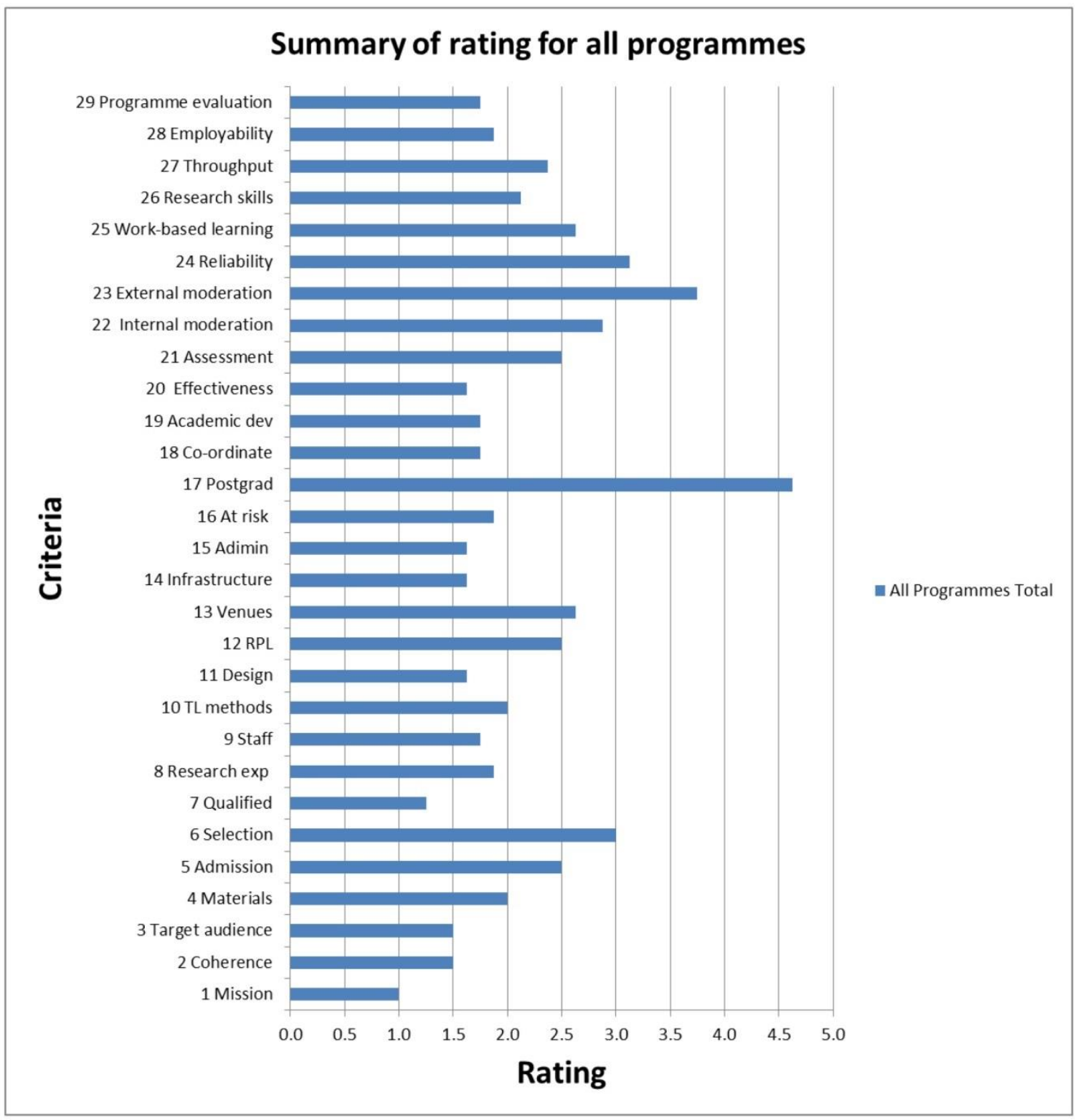

Figure 6: AD Programme Ratings

Evaluation notes highlighted programme collaboration as a key enabler for building communities of practice, for creating enabling environments, for building capacity, and for optimising resources. Critical reflections from the programme co-ordinators were informative; and they contributed to deepen the conceptualisations of the nature of the different programmes, as well as giving insight into programmes' components that need attention. Snippets from programme co-ordinators' reflections are listed in Table 6.

Table 6: Programme Co-ordinators' Reflections

"The teaching and learning introduction programme lays the foundation to optimise human potential and fostering an environment that is focussed on teaching, learning, scholarship, student success and humanising pedagogy.

The process of putting the programme on paper in an attempt to formalise it has pointed to various 
shortcomings in the programme, based on the criterion provided. In reflecting on the initial evaluation, I realised that I would need to re-analyse the programme based on how it is positioned. It is not appropriate to evaluate the programme in isolation, as it is unmistakably connected to the Scholarship of Teaching and Learning programme."

"Information shared increases insight into good teaching practices. Reflection on assumptions about and expectations of students, and increases ethical reflection which promotes self-improvement are highlighted as valuable in participants' feedback. The participation in the programme and the evaluation of the programme are used to inform planning for the following year. The academics are giving us feedback through evaluations that they are satisfied with the programme as a whole and that it is relevant as it makes them improve their teaching and assessment practices. They are satisfied with the delivery and assessment practice used in the programme especially the Moodle delivery mode."

"From the evaluation it has become apparent that one of this programme's strengths is that it gives opportunities to lecturers to reflect on their own teaching practices as well as opportunities to improve their teaching. This improves lecturers' employability and it has a direct impact on improving student learning. Another strength is that, while over-stretched at present, the programme has much potential and includes areas which could even be developed into separate programmes such as a fully-fledged Writing Across The Curriculum programme and a programme for researching the teaching and learning of academic writing. The weakness of this programme is the staff members are not sufficient in either number or seniority to carry out all the tasks that have been allocated to them."

"Decisions that we make about blended learning, learning design and online assessment are embedded in our views, assumptions and perceptions that make up our philosophy of teaching with technologies within the context of university values with a strong link to the value of 'ubuntu'."

"From 2008, this programme's services have been aligned with the institution's strategic priorities of improving black and coloured students' pass and graduation rates. For example, academics' awareness about the Language Policy, which leads to its implementation in classrooms and the multilingual glossaries that are developed in this programme, provide teaching and learning support, particularly for the above mentioned students."

"The SoTLC programme creates and sustains a responsive learning environment conducive to excellence in teaching and learning and fostering holistic student success. It promotes ongoing professional staff development with respect to teaching practices. The programme strives to develop strategies to encourage academics and professional support staff to be reflective practitioners who increasingly engage in the Scholarship of Teaching and Learning (SoTL). It provides forums for academics and professional support staff to publicly share good practices to enhance student learning and success."

"The Teaching Development Online Data System (TDODS) system, as it would come to be known, was developed according to the specification requirements of the Senior Manager as an attempt to revolutionise the reporting process required of staff."

Refining the evaluation instrument, as described above, led to a revised review instrument, which was applied to the AD programmes.

\section{RESULTS FROM THE REVISED SELF-EVALUATION REPORTS}

A review of the results from the revised self-evaluation reports was analysed; and a summary of the AD programme review results is displayed in Figure 7.

From the graph (Figure 7), it is apparent that the review results concurred with the previous review results. The criteria related to formal assessment and moderation was mostly not applicable, as only the two formal, accredited programmes conduct formal assessments. Each programme co-ordinator interpreted their programmes results, gave feedback and added reflective comments. A few examples of these notes and comments are listed in Table 7. 


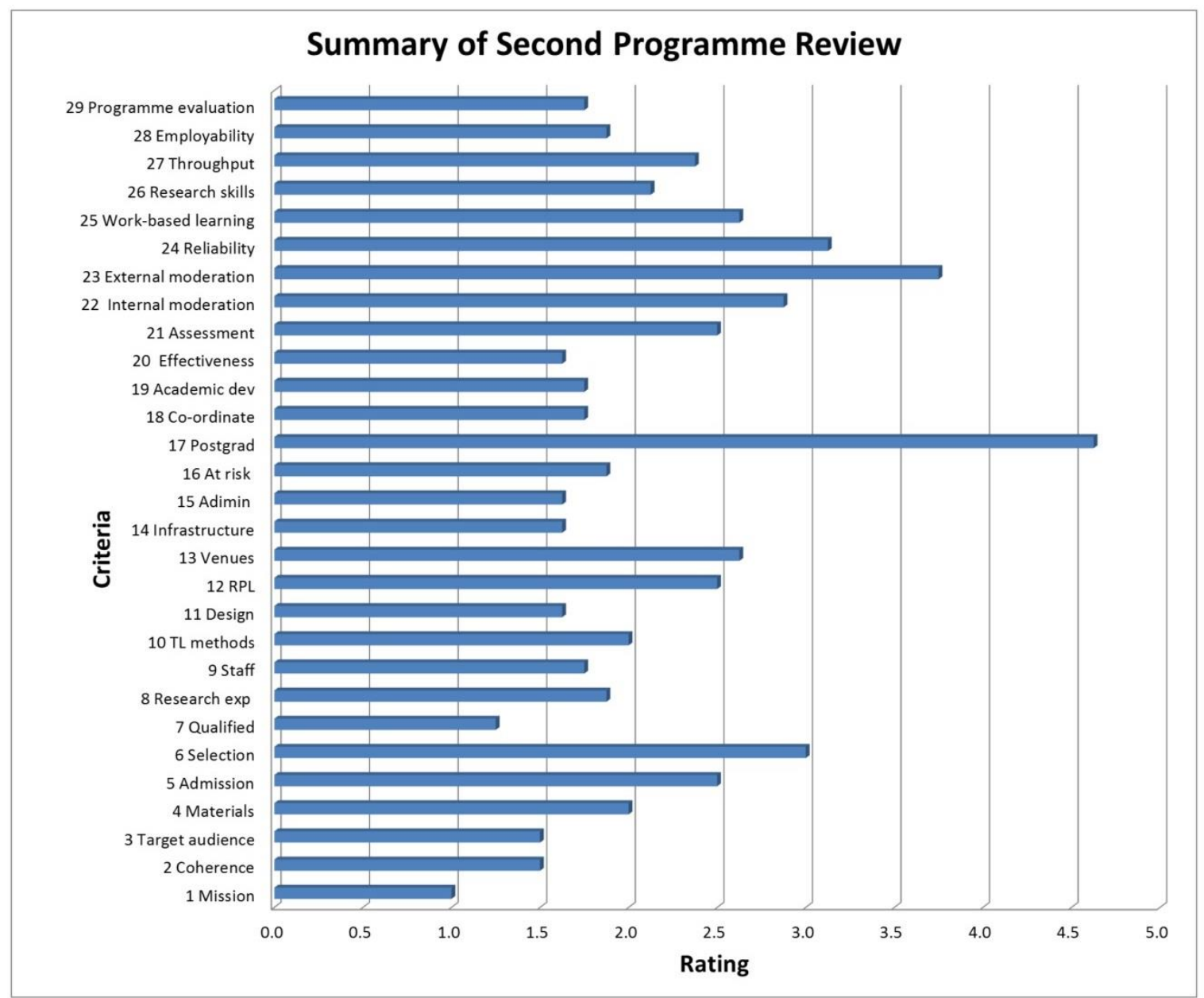

Figure 7: Summary of the Second Programme Review

Table 7: Programme Co-ordinators' Notes and Comments

"Scholarship of Teaching and Learning Certificate (SoTLC) is a programme that offers a collaborative space for TL development at the university to explore 'teaching for learning'. It positions the Scholarship of Teaching and Learning as a pathway to excellence. The programme's objectives are to work collaboratively with academics, especially novice academics, to enable life-long learning and self-directed reflective practitioners."

Suggested change implementation strategies included:

"Accelerate change implementation by creating awareness through marketing communications and also by providing structured support programmes for Blended Learning users. Also promote engagement through interactive workshops, demonstrations and presentations as well as online availability of specialised support. Foster commitment by weaving Blended Learning into the organisational culture." Interventions that may optimise the AD system include:

- Offering structured support tools to provide scaffolding and to direct lecturers and students.

- Identifying and actively involving different role players.

- Developing appropriate recognition and incentive systems for academic staff to reward excellence in respect of the scholarship of engagement.

- Prioritising professional development of staff through integration of internal staff development opportunities/interventions and allocating the necessary resources to various units according to transparent criteria.

- Developing a system able to capture and store data for recall for the Evaluation of Teaching and Modules programme. This will allow for comparative data and collaboration, however, the results need to remain confidential. 


\section{SUMMARY OF CRITERIA RATINGS RELATED TO PROGRAMME DESIGN AND ACADEMIC DEVELOPMENT}

To link the review results to the programme design, the team identified the criteria ratings related to programme design and academic development (Figure 8).

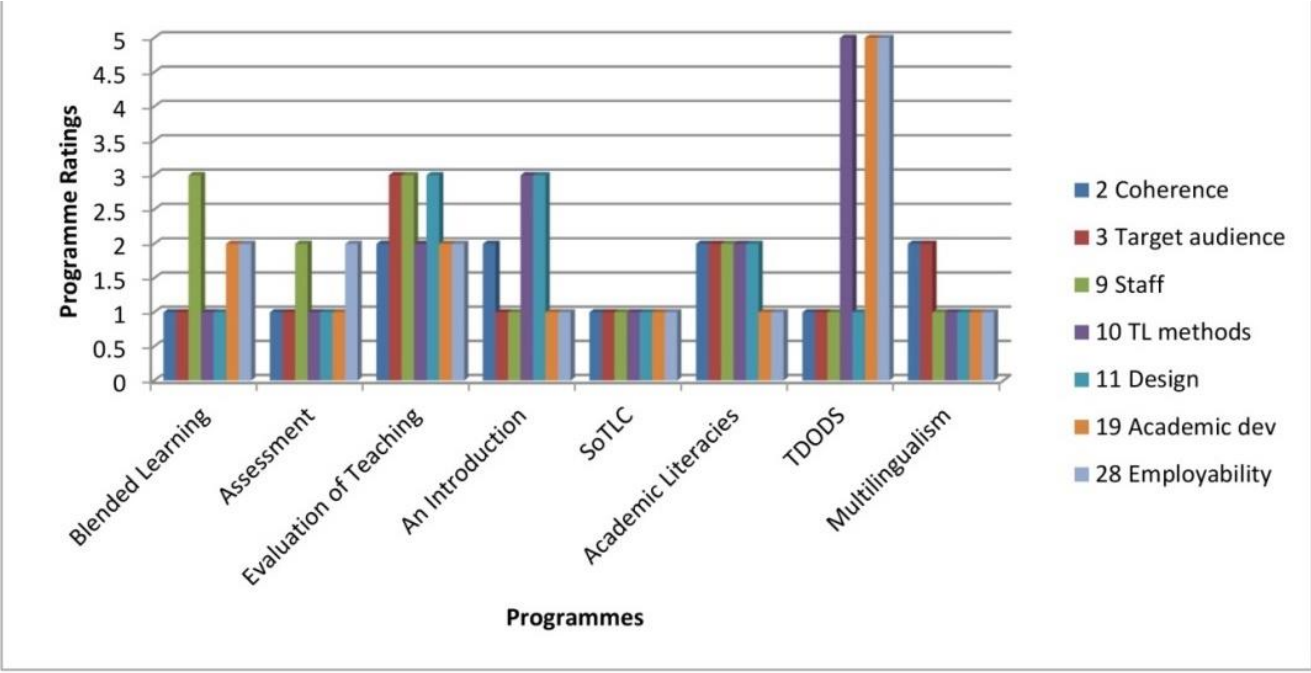

Figure 8: Criteria Ratings Important for Programme Design and AD

Ratings for these were between 1.5. and 2.0, which indicate that the minimum standards were met. The TDODS programme was rated higher; as the programme was deliberately developed and custom-made for the Teaching Development Unit, according to the relevant design specifications. Criteria 2 (coherence), 3 (target audience), 9 (staff complement), 10 (teaching and learning methods), 11 (design strategy), 19 (AD) and 28 (employability) specifically relate to programme design and $\mathrm{AD}$. The ratings for these indicate opportunities for programme redesign and intervention. (Table 8).

Table 8: Opportunities for Programme Re-design and Intervention

\begin{tabular}{|c|c|c|}
\hline $\begin{array}{l}\text { Criterion } \\
\text { number }\end{array}$ & Description & Programmes for redesign \\
\hline 2 & Coherence & $\begin{array}{l}\text { Evaluation of teaching and modules; Teaching and Learning: An } \\
\text { Introduction; Multilingualism; Academic Literacies }\end{array}$ \\
\hline 3 & Target audience & $\begin{array}{l}\text { Evaluation of teaching and modules; Multilingualism; Academic } \\
\text { Literacies }\end{array}$ \\
\hline 9 & Staff & $\begin{array}{l}\text { Blended Learning; Assessment of Student Learning in HET; } \\
\text { Evaluation of teaching and modules; Academic Literacies }\end{array}$ \\
\hline 10 & $\begin{array}{l}\text { Teaching and learning } \\
\text { methods }\end{array}$ & $\begin{array}{l}\text { Evaluation of teaching and modules; Teaching and Learning: An } \\
\text { Introduction; TDODS; Academic Literacies }\end{array}$ \\
\hline 11 & Design and review & $\begin{array}{l}\text { Evaluation of teaching and modules; Teaching and Learning: An } \\
\text { Introduction; Academic Literacies }\end{array}$ \\
\hline 19 & $\begin{array}{l}\text { Academic development } \\
\text { initiatives }\end{array}$ & Blended Learning; Evaluation of teaching and modules \\
\hline 28 & Employability & $\begin{array}{l}\text { Blended Learning; Assessment of Student Learning in HET; } \\
\text { Evaluation of teaching and modules }\end{array}$ \\
\hline
\end{tabular}




\section{FINDINGS AND INTERPRETATION OF THE RESULTS}

Each programme co-ordinator interpreted their programme results, shared their findings with the team to consolidate and report. General impressions, systems approaches, participant reflections and evaluation-framework lenses, would highlight and communicate the research findings and interpretations.

\section{A. General impression lens}

Exploring AD programmes at the University, highlighted the following profiles of the nine AD programmes as: Research as a new programme, Electronic systems as a supportive programme within the AD Centre, Evaluation of Teaching and Modules requires re-conceptualisation, and Teaching and Learning: An Introduction as evolving. Two programmes, namely Blended Learning and Assessment of Student Learning in HET are credit-bearing programmes, and three programmes, SoTLC, Multilingualism and Academic Literacies are meeting the minimum requirements. The evaluation underlined the importance of alignment and collaboration between the programmes for example the linkages between the Introduction to Teaching and Learning programme with the SoTLC, Blended Learning and Assessment programmes.

Evaluation results indicate connectedness between all the programmes, which points to the criticality of close collaboration, holistic planning and shared action plans. All programmes have a common purpose to effect conceptual change, resulting in reflective and changing practices on all levels and layers of AD. Understaffed programmes, unclear roles and responsibilities, and sometimes unmanageable workloads are common concerns. Some needs highlighted by the evaluation of the Academic Literacies programme as supporting policies and structures, support to staff members when trying to adapt to new identities as AD professionals, and support and buy-in from top management.

\section{B. Systems theory lens}

The AD system and embedded programme sub-systems show a variety of similar, unique, blended, or overlapping input characteristics. Various processes are pushed or accelerated by positive and negative drivers and interventions, resulting in output to feedback as the input into the system, with positive or negative-system outcomes.

Table 9 provides a cryptic summary of the sub-systems of the AD programme system. 
Table 9: Sub-systems of the AD Programme*

\begin{tabular}{|c|c|c|c|c|c|c|}
\hline $\begin{array}{c}\text { Programme } \\
\text { Subsystem }\end{array}$ & $\begin{array}{c}\text { Characteris } \\
\text { tics }\end{array}$ & + Drivers & Input & Process & Interventions & Output \\
\hline Multilingualism & $\begin{array}{l}\text { Semi-formal, } \\
\text { on-going, } \\
\text { project } \\
\text { focused }\end{array}$ & $\begin{array}{l}\text { DHET, policy, } \\
\text { needs, positive } \\
\text { feedback loops }\end{array}$ & $\begin{array}{l}\text { Programme } \\
\text { characteristics, } \\
\text { structure and } \\
\text { content }\end{array}$ & $\begin{array}{l}\text { Programme } \\
\text { implementation }\end{array}$ & $\begin{array}{l}\text { Actions to } \\
\text { maximise + } \\
\text { and minimise - }\end{array}$ & $\begin{array}{l}\text { Indirect - pass } \\
\text { rate }\end{array}$ \\
\hline $\begin{array}{l}\text { Blended } \\
\text { Learning } \\
\text { Assessment }\end{array}$ & $\begin{array}{l}\text { Formal, SLP, } \\
\text { timeframe }\end{array}$ & $\begin{array}{l}\text { Vision 2020, } \\
\text { needs, positive } \\
\text { feedback loop }\end{array}$ & $\begin{array}{l}\text { Programme } \\
\text { characteristics, } \\
\text { structure and } \\
\text { content }\end{array}$ & $\begin{array}{l}\text { Scheduled } \\
\text { offerings }\end{array}$ & $\begin{array}{l}\text { Actions to } \\
\text { maximise }+ \\
\text { and minimise - }\end{array}$ & $\begin{array}{l}\text { Throughput, } \\
\text { Portfolio } \\
\text { assessment }\end{array}$ \\
\hline $\begin{array}{l}\text { Academic } \\
\text { Literacies }\end{array}$ & $\begin{array}{l}\text { Semi-formal, } \\
\text { ongoing, } \\
\text { open-ended } \\
\text { project focus }\end{array}$ & $\begin{array}{l}\text { DHET, needs, } \\
\text { positive } \\
\text { feedback loops }\end{array}$ & $\begin{array}{l}\text { Programme } \\
\text { characteristics, } \\
\text { structure and } \\
\text { content }\end{array}$ & $\begin{array}{l}\text { Programme } \\
\text { implementation }\end{array}$ & $\begin{array}{l}\text { Actions to } \\
\text { maximise + } \\
\text { and minimise - }\end{array}$ & $\begin{array}{l}\text { Output of } \\
\text { programme }\end{array}$ \\
\hline SoTLC & $\begin{array}{l}\text { Semi-formal, } \\
\text { non-credit } \\
\text { bearing } \\
\text { certificate, } \\
\text { timeframe }\end{array}$ & $\begin{array}{l}\text { Needs, positive } \\
\text { feedback loops }\end{array}$ & $\begin{array}{l}\text { Programme } \\
\text { characteristics, } \\
\text { structure and } \\
\text { content }\end{array}$ & $\begin{array}{l}\text { Programme } \\
\text { implementation }\end{array}$ & $\begin{array}{l}\text { Actions to } \\
\text { maximise }+ \\
\text { and minimise - }\end{array}$ & $\begin{array}{l}\text { Attendance, } \\
\text { completion rate, } \\
\text { completion of } \\
\text { tasks, } \\
\text { portfolios, } \\
\text { participants' } \\
\text { feedback }\end{array}$ \\
\hline TDODS & $\begin{array}{l}\text { Semi-formal, } \\
\text { online } \\
\text { database, } \\
\text { ongoing } \\
\text { administration }\end{array}$ & $\begin{array}{l}\text { Positive } \\
\text { feedback loop } \\
\text { by interventions } \\
\text { such as training } \\
\text { and support to } \\
\text { users as well as } \\
\text { programme } \\
\text { adjustment }\end{array}$ & $\begin{array}{l}\text { Staff data } \\
\text { input }\end{array}$ & $\begin{array}{l}\text { Database for } \\
\text { reports }\end{array}$ & $\begin{array}{l}\text { Actions to } \\
\text { maximise }+ \\
\text { and minimise - }\end{array}$ & $\begin{array}{l}\text { User reports; } \\
\text { user stats; data } \\
\text { analysis; user } \\
\text { behaviour } \\
\text { patterns and } \\
\text { trends; activity } \\
\text { logs; activity } \\
\text { reports }\end{array}$ \\
\hline
\end{tabular}

* The format descriptions of the programmes were linked to the descriptions of the CHE as "formal programmes that lead to a range of NQF registered qualifications" (Singh 2004, 139 and 147). For example, the Blended Learning and the Assessment of Student Learning Modules linked to the PGCHET formal qualification. As in the case of the semi-formal programmes, a series of short workshops contributed to some form of certification or a well-defined outcome. Each of the programmes could be linked to one or more of the different programme modes as described by Prebble et al. (2004).

Important to note is that choices regarding the characteristics, mode, format, impact measuring and model of the programme, determine the programme outcome (Prebble et al. 2004). They further describe the six theoretical models proposed by Gilbert and Gibbs (1998) and highlight that the "intended outcomes of these programmes will depend on the underlying model and should therefore determine the way in which the programmes are assessed" (Prebble et al. 2004, 42).

\section{Reflective lens}

The analysis of programme evaluation reflections indicated that developing opportunities for academics to reflect on and develop their own practices are important programme design features. Reflective models advocating the development of reflective practitioners are widely used as theoretical frameworks for AD programmes for example Gilbert and Gibbs (1998) and Guskey’s (2002) five-level model. See example (Table 10). 
Table 10: Analysis of Programme Evaluation Reflections

We apply the components of change (awareness, engagement and commitment) as follows:

- $\quad$ Awareness [raising]: our communiqués to staff, the information on our website, how we help develop lecturers' study guides according to the principles of best practice in teaching and learning, the tone of our individual face-to-face or email interactions and agreements with academics, how we respond to collaborative assignment or module design or how we conduct collaborative classroom sessions.

- $\quad$ Engagement: We engage with academics in the workshops for academics that we offer, when we device collaborative writing development strategies or design study guides or modules together.

- $\quad$ [Creating opportunities for giving evidence of] Commitment: When an academic attends the Academic Literacies opportunities we create and build into their programme design the changes we suggest and/or is willing to collaborate with us in a longer term writing development strategy (e.g. for a year), we commit to providing sustained support in the classroom when needed, responding to student drafts (either face-toface or online) as well as to having reflective sessions with the academic to discuss what worked and what did not work.

\section{Evaluation-framework lens}

The programme component framework captured the characteristics of AD programmes; and it is summarised in Table 11 as, format, purpose, approach, alignment, roles and role-players, processes and procedures, and outcomes, all of which capture the characteristics of the programmes within a specific context. These are summarised in Table 11 and they show elements from several of the six theoretical AD programme models proposed by Gilbert and Gibbs (1998). The six models are summarised by Prebble et al. $(2004,42)$ as:

"Behavioural change models - that focus on changing the teacher's behaviour in the classrooms. Developmental models - based on the idea that teachers change their focus of attention over the course of their career, from self to subject to student (passive) and finally to student (active). Reflective practice models - that advocate the development of reflective practitioners. Conceptual change models - that maintain teachers' conceptions about teaching are linked to their teaching intentions and strategies. Student learning models - that focus on students' approaches to study, and their perceptions of their learning environment. Hybrid models - that combine elements of several models."

Table 11: Summarised AD Programme Characteristics

\begin{tabular}{|c|c|c|c|c|c|c|}
\hline Format & Purpose & Approach & Alignment & $\begin{array}{l}\text { Role-players } \\
\text { and roles }\end{array}$ & $\begin{array}{l}\text { Processes } \\
\text { and } \\
\text { Procedures }\end{array}$ & Outcomes \\
\hline $\begin{array}{l}\text { Delivery } \\
\text { mode: } \\
\text { Electronic; } \\
\text { online, Blended } \\
\text { Learning, face- } \\
\text { to-face } \\
\text { Offering: } \\
\text { Formal SLP } \\
\text { credit bearing, } \\
\text { non-credit } \\
\text { bearing, semi- } \\
\text { formal, non- } \\
\text { formal, Ad Hoc } \\
\text { Teaching and } \\
\text { learning } \\
\text { opportunities: }\end{array}$ & $\begin{array}{l}\text { Programme } \\
\text { specific, e.g. } \\
\text { To engage in } \\
\text { dialogue, build } \\
\text { relationships } \\
\text { and } \\
\text { communities } \\
\text { of practice. } \\
\text { Build capacity. } \\
\text { Optimise } \\
\text { processes and } \\
\text { procedures. } \\
\text { Facilitate } \\
\text { teaching, }\end{array}$ & $\begin{array}{l}\text { Developmental } \\
\text { needs driven, } \\
\text { research } \\
\text { orientated, } \\
\text { enabling } \\
\text { spaces, } \\
\text { multiliteracies } \\
\text { approach, } \\
\text { facilitative, } \\
\text { humanising, } \\
\text { constructive, } \\
\text { active } \\
\text { learning; } \\
\text { Participatory } \\
\text { dialogue, } \\
\text { influential e.g. } \\
\text { curriculum }\end{array}$ & $\begin{array}{l}\text { Institutional } \\
\text { Vision2020. } \\
\text { Selected } \\
\text { academic } \\
\text { programmes. } \\
\text { Administration } \\
\text { programmes. } \\
\text { HR } \\
\text { programmes. }\end{array}$ & $\begin{array}{l}\text { Programme } \\
\text { and learning } \\
\text { designers, } \\
\text { project } \\
\text { leaders, } \\
\text { academic } \\
\text { developers. } \\
\text { Interaction } \\
\text { with faculties, } \\
\text { departments, } \\
\text { students, and } \\
\text { selected } \\
\text { groups and } \\
\text { project } \\
\text { members. }\end{array}$ & $\begin{array}{l}\text { Regulated by } \\
\text { various } \\
\text { policies. } \\
\text { Vision } 2020 . \\
\text { Institutional } \\
\text { strategic plan. } \\
\text { Programme } \\
\text { specific } \\
\text { processes and } \\
\text { procedures. } \\
\text { Academic } \\
\text { development } \\
\text { activities. }\end{array}$ & $\begin{array}{l}\text { Certification. } \\
\text { Policy } \\
\text { development. } \\
\text { Adoption of } \\
\text { new } \\
\text { approaches } \\
\text { and practices. } \\
\text { Programme } \\
\text { specific } \\
\text { outcomes, } \\
\text { Reflective } \\
\text { practice. } \\
\text { Accelerated }\end{array}$ \\
\hline
\end{tabular}




\begin{tabular}{|c|c|c|c|c|c|c|}
\hline Format & Purpose & Approach & Alignment & $\begin{array}{l}\text { Role-players } \\
\text { and roles }\end{array}$ & $\begin{array}{l}\text { Processes } \\
\text { and } \\
\text { Procedures }\end{array}$ & Outcomes \\
\hline $\begin{array}{l}\text { Presentations, } \\
\text { demonstrations, } \\
\text { workshops, } \\
\text { consultations, } \\
\text { monitoring, } \\
\text { dialogue } \\
\text { Levels: } \\
\text { Faculty, } \\
\text { department, } \\
\text { group, } \\
\text { individual }\end{array}$ & $\begin{array}{l}\text { learning and } \\
\text { assessment } \\
\text { opportunities. } \\
\text { Enhance } \\
\text { academic } \\
\text { practices. } \\
\text { Create } \\
\text { collaborative } \\
\text { spaces. }\end{array}$ & design. & & & & $\begin{array}{l}\text { change } \\
\text { implementation. }\end{array}$ \\
\hline
\end{tabular}

Based on our programme evaluation we support the notion that $\mathrm{AD}$ development and the implementation of $\mathrm{AD}$ programmes remain a viable option for teaching and learning in $\mathrm{HE}$. We were also encouraged by the research report published by Prebble et al., 2004, who list 13 propositions for improving student learning outcomes based on literature analysis and research evidence. They propose that, "Through a variety of academic development interventions, teachers can be assisted to improve the quality of their teaching" (Prebble et al. 2004, 13). Important propositions linked to this are that "Teachers can be assisted to improve the quality of their teaching through obtaining feedback, advice and support for their teaching from a colleague or academic development consultant" (Prebble et al. 2004, 37). Followed by "Student assessments are among the most reliable and accessible indicators of the effectiveness of teaching." (Prebble et al. 2004, 41) and continue by proposing that "Intensive and comprehensive staff development programmes can be effective in transforming teacher's beliefs about teaching and learning and their teaching practice. In particular, teachers can be assisted to shift from a teacher-centred approach to a learner-centred approach, and to align all the elements of the teaching situation in order to achieve positive student outcomes". (Prebble et al. 2004, 48).

From the evaluation data, it is evident that all our programmes, in nature, are learnercentred, following a participatory programme development approach, supported by the hybrid model which allows for a combination of several models (Prebble et al. 2004, 44). Our programmes allow for a range of choices, namely, ad hoc combinations for teaching with technology to include skills training, workshops, and learning design courses. Needs-driven customisable, dynamic design application and flexible content in the formal programmes contribute to achieve the set outcomes. The focus of the nine evaluated programmes is on process where the learning is experienced as developmental, participatory with active involvement of the learners (academic staff as students and their students when it comes to student evaluation of teaching). 


\section{OUTCOME: GENERIC PROGRAMME DESIGN SPECIFICATIONS}

A synthesis from programme and consolidated reports, input from evaluation reports and research findings, provided input for programme design specifications. Input variables include the context, resources, target population, philosophical approaches, conceptual and theoretical frameworks, educational approaches, programme components, minimum standards, academic development opportunities, and programme structure. These contributed towards a blueprint document for a generic AD programme design (Table 12), as an important outcome of the study in terms of a systematic and consistent approach to data-driven programme design. The latter facilitates not only for a focused point of departure (input elements) embedded in contextual features as drivers to enable or restrain the process, but also for customisation and dynamic programme changes dependant on the programme specific model, -mode and -outcomes (Prebble et al. 2004; Guskey 2002; Chalmers and Gardiner 2015).

Table 12: Data-driven Design Specifications and Blueprint for Generic AD Programme Design

\begin{tabular}{|c|c|c|c|}
\hline \multicolumn{4}{|c|}{ Design Specifications and Blueprint Document for Generic Academic Programme Design } \\
\hline Phase focus & Detailed focus & Choices & Output \\
\hline Educational philosophy & $\begin{array}{l}\text { Philosophical } \\
\text { underpinnings aligned } \\
\text { with contextual vision } \\
\text { and mission }\end{array}$ & Humanising pedagogy & $\begin{array}{l}\text { Descriptive } \\
\text { document }\end{array}$ \\
\hline Logic model & $\begin{array}{l}\text { Models/Theories of } \\
\text { change } \\
\text { Models/Theories of } \\
\text { action }\end{array}$ & $\begin{array}{l}\text { Components of change } \\
\text { (awareness, engagement, } \\
\text { commitment) } \\
\text { Change implementation to } \\
\text { create conceptual change }\end{array}$ & $\begin{array}{l}\text { Descriptive } \\
\text { document }\end{array}$ \\
\hline Educational approach & $\begin{array}{l}\text { Communicational, } \\
\text { Reflective } \\
\text { Collaborative }\end{array}$ & $\begin{array}{l}\text { Underlying educational } \\
\text { approach for programme }\end{array}$ & $\begin{array}{l}\text { Descriptive } \\
\text { document }\end{array}$ \\
\hline Programme components & $\begin{array}{l}\text { Field; Format; Offerings, } \\
\text { Purpose; Approach; } \\
\text { Alignment; Role-players; } \\
\text { Roles; Processes and } \\
\text { procedures; Outcomes }\end{array}$ & Programme specific & Component table \\
\hline Minimum standards & Quality criteria & $\begin{array}{l}\text { Quality criteria related to } \\
\text { contextual vision and mission; } \\
\text { coherence; recruitment; staff; } \\
\text { outcomes; infrastructure; } \\
\text { administrative systems; policies; } \\
\text { curriculum development; } \\
\text { achievements; feedback results }\end{array}$ & Standard list \\
\hline \multirow{8}{*}{$\begin{array}{l}\text { Academic development } \\
\text { opportunities }\end{array}$} & Purpose & \multirow{8}{*}{$\begin{array}{l}\text { Programme / offering sequence } \\
\text { and design specifications }\end{array}$} & \multirow{8}{*}{$\begin{array}{l}\text { Design specification } \\
\text { document }\end{array}$} \\
\hline & Delivery mode & & \\
\hline & Reflection opportunities & & \\
\hline & Learning outcomes & & \\
\hline & Subject matter chunks & & \\
\hline & Activities & & \\
\hline & Tasks & & \\
\hline & Feedback opportunities & & \\
\hline Structure levels & Module structure & $\begin{array}{l}\text { Sequence and relationship of } \\
\text { learning units (academic } \\
\text { development opportunities) }\end{array}$ & $\begin{array}{l}\text { Flow chart of } \\
\text { module structure }\end{array}$ \\
\hline
\end{tabular}




\section{Explanatory notes about Table 12}

Generic design specifications provide a framework for an AD programme blueprint, which could guide programme development and implementation within the South African, HE context. The generic AD programme design (Table 12) proposed does not espouse a generic set of prescriptive generic skills or a random pick and mix selection of programme components to create training and workshop opportunities for participants. On the contrary, generic in the description refers to design specifications, which were distilled from the analysis and evaluation activities done by the AD participants in the project. The set of generic design specifications not only, profiles a framework application in the different $\mathrm{AD}$ and teaching domains, but also enables the customisation, in terms of the specific programme requirements as per domain or discipline. The specific context, mode, and model determine the set of design specifications selected for a specific application. Mapping the data-driven programme design specifications, supported by research findings, to AD programme modes (Prebble et al. 2004, 25), models (Prebble et al. 2004, 42) and impact measuring (Guskey 2002; Chalmers and Gardiner 2015) provide a useful matrix for decision-making.

\section{DISCUSSION AND IMPLICATIONS FOR HIGHER EDUCATION}

Quinn (2012, 6-7) describes three paradigms in teaching development (from Light and Cox 2000) as the ad hoc paradigm where participants draw on experience and informally acquire the required skills as they move along. The skills paradigm sees teaching development as a skill-set that one needs to acquire by attending workshops and training sessions. Within the professional paradigm, participants are encouraged to become reflective and critical professionals. Analysis and evaluation of the nine AD programmes in this study applied four lenses namely general impressions, reflection, systems theory and thinking, and evaluation frameworks. ${ }^{1}$ Through these lenses it became evident that all programmes included elements from all three paradigms mentioned by Quin (2012) to suit the programme nature and purpose. The nature of the $\mathrm{AD}$ programme e.g. the characteristics, model, mode, approach and outcomes would populate the programme design to create a unique blueprint for each of the programmes. Findings informed a generic design specification list and blueprint document for $\mathrm{AD}$ programme design. The importance of customizable programme blueprints for the development of different programme modes and models is illustrated by the programme evaluation findings. Examples are programme modes that ranged from formal credit bearing, short learning to group or one-on-one training, consultation and student feedback and evaluation. Different programme models were identified and the application of hybrid models were find to be useful. According 
to Prebble et al. (2004) it is the mixture of "programme objectives that has motivated most of the more systematic and intensive programmes of academic development" and that is adding to "currently contributing to the international pressure to introduce accredited and mandatory programmes in systems of higher education" (Prebble et al. 2004, 44). They also found that a combination of the conceptual change and student learning approaches informed the outcomes of intensive AD programmes. (Prebble et al. 2004, 91). The CHE report on "Learning to Teach in Higher Education in South Africa" (CHE 2017, 12) highlights the importance of academic development and mentions that universities are becoming more intentional to develop the required competencies. AD programmes are core to these endeavours (Chalmers and Gardiner, 2015). Study findings concur that a range of informal, formal, ad hoc, group, individual, "theoretical and practice-based learning opportunities, are important for professional growth and development from enrolment on formal professional development programmes to participation in informal supportive networks within the AD context" (CHE 2017, 15 and 2829). Therefore, the generic AD programme design (Table 12) provides a holistic, integrated framework, which allows for choices about theoretical approaches (e.g. humanizing pedagogy and heutagogical approaches), linked to a continuum of different programmes modes, models, and structural elements, within specific contexts. Analysis of our programmes highlighted linkages as a strength in our programme system as it provides multiple opportunities for engagement, reflection, and relevant theoretical knowledge sharing. Guskey (2002, 48 cited in the CHE 2017 report) is of opinion that a "lack of institutional support can sabotage any professional development effort even when the individual aspects of professional development are done right" (CHE 2017, 28). Within the South African context we concur with the CHE $(2017,31)$ report which emphasizes the importance of AD to create, enable and sustain enabling environments for enhancing teaching and learning in Higher Education.

\section{CONCLUSION}

Programme evaluation of the nine programmes highlighted that we offer AD programmes ranging from formal credit bearing to informal supportive networks (CHE 2017, 28). Each of these programmes plays an important role in the HE context and it is now generally accepted that $\mathrm{AD}$ programmes remain a viable option for enhancing teaching and learning in $\mathrm{HE}$. (Chalmers and Gardiner 2015, 53; CHE 2017, 31). Therefore, in the South African context where there is a growing understanding of the broader contexts and the range of learning opportunities for AD that impact on what teachers can achieve (CHE 2017, 31), the importance of research-based, data-driven decision making is eminent. Through the application of an evaluation research approach to systematically analyse nine AD programmes, we were enabled 
to move toward a scholarly approach in reviewing our programmes. Outputs include a datadriven perspective in the formulation of a generic specification template and blueprint for $\mathrm{AD}$ programme design and redesign. The resulting output, in turn, feeds back as input into the second and third cycles, which focus on establishing the suitability of the redesigned programmes in determining the desired conceptual change in participants' teaching practice and consequent impact on student learning.

\section{ACKNOWLEDGEMENTS}

The University Teaching Development Innovation Fund for supporting this project.

The language editor.

\section{NOTE}

1. Some of the research findings were presented in a live presentation on 21 November 2014 at the HELTASA Conference 2014, at the University of Free State, Bloemfontein, South Africa.

\section{REFERENCES}

Bamber, V. 2008. Evaluating lecturer development programmes: Received wisdom or self-knowledge?, International Journal for Academic Development 13(2): 107-116, DOI: 10.1080/13601440802076541 To link to this article: http://dx.doi.org/10.1080/ 13601440802076541 (Accessed 15 July 2014).

Berens, L. V. 2013. The self of the self-organizing system. Telos Publications. http://lindaberens.com/ resources/methodology-articles/the-self-of-the-self-organizing-system/ (Accessed 13 October 2016).

Boughey, C. 2007. Marrying equity and efficiency: The need for third generation academic development. Perspectives in Education 25(3).

CALPRO. 1997. California Adult Literacy Professional Development Project Online. Section 4: Evaluating Professional Development A Framework for Adult Education. A publication of building professional development partnerships for adult educators' project. http://www.calproonline.org/pubs/Eval4.pdf (Accessed 1 November 2014).

Capra, F. 1997. The web of life. The Schrödinger lecture series. Dublin, 9 September, 1997. http://www-users.york.ac.uk/ 1sdc1/SysBiol/capra.weboflife.schrodingerlecture.1997.pdf (Accessed 14 October 2016).

CGIAR. 2013. Research program on aquatic agricultural systems. 2014. AAS 2013 Evaluating natural resource management programs. Annual Report: AAS-2014-32. Penang, Malaysia: CGIAR. http://pubs.iclarm.net/resource_centre/AAS-2013-annual-report.pdf (Accessed November 2014).

Chalmers, D. and D. Gardiner. 2015. The measurement and impact of university teacher development programs. Educar 51(1): 53-80.

CHE see The Council of Higher Education.

Gibbs, G. and M. Coffey. 2004. The impact of training of university teachers on their teaching skills, their approach to teaching and the approach to learning of their students. Active Learning in Higher Education 5(1): 87-101.

Gilbert, A. and G. Gibbs. 1998. A proposal for an international collaborative research programme to identify the impact of initial training on university teachers. Research and Development in Higher Education 21: 131-143. 
Guskey, T. R. 2002. Does it make a difference? Evaluating professional development. Educational Leadership 59(6): 45-51.

Ho, A. S. P. 1998. A conceptual change staff development programme: Effects as perceived by the participants. International Journal for Academic Development 3(1): 24-38.

Ho, A. S. P. 2000. A conceptual change approach to staff development: A model for programme design. International Journal for Academic Development 5(1): 30-41.

Ho, A. S. P., D. Watkins and M. Kelly. 2001. The conceptual change approach to improving teaching and learning: An evaluation of a Hong Kong staff development programme. Higher Education 42(2): 143-169.

Joyce, B. and B. Showers. 1995. Student achievement through staff development: Fundamentals of school renewal. 2nd Edition. White Plains, N.Y.: Longman.

Killion, J. 2005/2006. Evaluating the impact of professional development in eight steps. Professional development. The Evaluation Exchange XI(4): 1-24 Harvard Family Research Project Harvard Graduate School of Education. http://www.hfrp.org/evaluation/the-evaluation-exchange/issuearchive/professional-development (Accessed 13 October 2016).

Knowlton, L. W. and C. C. Phillips. 2013. The logic model guidebook: Better strategies for great results. Second Edition. SAGE Publications. http://www.sagepub.com/upm-data/50363_ch_1.pdf (Accessed 1 November 2014)

Kutner, M., R. Sherman, J. Tibbetts and L. Condelli. 1997. Evaluating professional development: A framework for adult education. A Publication of Building Professional Development Partnerships for Adult Educators Project by Pelavin Research Institute. Washington, DC. Pelavin Research Associates. http://www.calpro-online.org/pubs/evalmon.pdf (Accessed 1 November 2014).

Light, G. and R. Cox. 2000. Learning and teaching in higher education: The reflective professional. London: Sage.

McAlpine, L., C. Amundsen, M. Clement and G. Light. 2009. Rethinking our underlying assumptions about what we do and why we do it: Academic development as a case. Studies in Continuing Education 31(3): 261-280.

Millar, A., R. S. Simeone and J. T. Carnevale. 2001. Logic models: A systems tool for performance management. Evaluation and Program Planning 24: 73-81.

MMWR. 1999. Using indicators for program planning and evaluation framework for program evaluation in public health 48(RR11): 1-40. https://www.cdc.gov/mmwr/preview/mmwrhtml/ rr4811a1.htm (Accessed 24 August 2016).

Mouton, J. 2001. How to succeed in your master's and doctoral studies: A South African guide and resource book. Van Schaik. Pretoria. South Africa.

Patton, M. 1997. Utilization-focused evaluation: The new century text. 3rd Edition. Thousand Oaks, CA: Sage.

Patton, M. 2002. Two decades of developments in qualitative inquiry. A personal, experiential perspective. Qualitative Social Work 1(3): 261-283. Copyright (C2002 Sage Publications London, Thousand Oaks, CA and New Delhi 1473-3250[200209]1:3;261-283;026636.

Prebble, T., H. Hargraves, L. Leach, K. Naidoo, G. Suddaby and N. Zepke. 2004. Impact of Student Support Services and Academic Development Programmes on Student Outcomes in Undergraduate Tertiary Study Report to the Ministry of Education. http://www.academia.edu/ 1415924/Impact_of_student_support_services_and_academic_development_programmes_on_st udent_outcomes_in_undergraduate_tertiary_study_A_synthesis_of_the_research (Accessed 14 October 2016).

Quinn, L. (Ed.). 2012. Re-imagining academic staff development: Spaces for disruption. Stellenbosch: SUN MeDIA.

Rogers, P. J. and B. Williams. 2006. Evaluation for practice improvement and organizational learning. In The Sage Handbook of Evaluation, ed. I. F. Shaw, J. C. Greene and M. M. Mark. London: Sage Publications. 
Senge, P. M. 2006. The fifth Discipline: The art and practice of the learning organization. 2nd Edition. New York: Doubleday Currency.

Shadish, W. R. Jr., T. D. Cook and L. C. Leviton. 1991. Foundations of program evaluation. Newbury Park, CA: Sage.

Singh, M. 2004. ITL Introduction to the HEQC's improving teaching and learning resources. Published by the South African Council on Higher Education (CHE): 1-187. http://www.che.ac.za/sites/ default/files/publications/Improving\%20Teaching\%20\%26\%20Learning_ITL_Resources.pdf (Accessed 13 October 2016).

The Council on Higher Education. 1997. South African Education White Paper 31997. http://www.che.ac.za/sites/default/files/publications/White_Paper3.pdf (Accessed 13 October 2016).

The Council on Higher Education. 2004. Council on Higher Education: Criteria for Programme Accreditation. http://www.che.ac.za/sites/default/files/publications/CHE_accreditation_criteria_ Nov2004_0.pdf (Accessed 13 October 2016).

The Council on Higher Education. 2016. South African Higher Education Reviewed: Two decades of democracy. http://www.che.ac.za/sites/default/files/publications/CHE_South\%20African\%20 higher\%20education\%20reviewed\%20-\%20electronic_0.pdf (Accessed 26 September 2017).

The Council on Higher Education. 2017. Learning to teach in higher education in South Africa. http://www.che.ac.za/sites/default/files/publications/PUB_HE\%20Monitor\%2014_20170401.pdf (Accessed 26 September 2017).

Weis, H. and L. Klein. 2005/2006 Pathways from workforce development to child outcomes. Professional Development. The Evaluation Exchange XI (4): 1-24. Harvard Family Research Project Harvard Graduate School of Education. http://www.hfrp.org/evaluation/the-evaluationexchange/issue-archive/professional-development (Accessed 13 October 2016).

Weisburd, C. and T. Sniad. 2005/2006. Theory of action in practice. Professional development. The Evaluation Exchange XI(4): 1-24 Harvard Family Research Project Harvard Graduate School of Education. http://www.hfrp.org/var/hfrp/storage/original/application/1ef9f773781dd0b1e2d237 f6c8af939e.pdf

Wikipedia. n.d. Abductive reasoning - Wikipedia, the free encyclopaedia. https://en.wikipedia.org/ wiki/Abductive_reasoning 